\title{
The use of reference gene selection programs to study the silvering transformation in a freshwater eel Anguilla australis: a cautionary tale
}

\author{
Alvin N Setiawan", P Mark Lokman
}

\begin{abstract}
Background: Quantitative real-time PCR (qPCR) has been the method of choice for the quantification of mRNA. Due to the various artifactual factors that may affect the accuracy of $\mathrm{qPCR}$, internal reference genes are most often used to normalize qPCR data. Recently, many studies have employed computer programs such as GeNorm, BestKeeper and NormFinder in selecting reference genes, but very few statistically validate the outcomes of these programs. Thus, in this study, we selected reference genes for qPCR of liver and ovary samples of yellow (juvenile), migratory (silver) and 11-KT treated juveniles of New Zealand shortfinned eels (Anguilla australis) using the three computer programs and validate the selected genes statistically using REST 2009 software and the Mann-Whitney test. We also tested for the repeatability of use for the best reference genes by applying them to a data set obtained in a similar experiment conducted the previous year.

Results: Out of six candidate genes, the combination of $18 \mathrm{~s}$ and eef 1 was found to be the best statistically validated reference for liver, while in ovary it was 136. However, discrepancies in gene rankings were found between the different programs. Also, statistical validation procedures showed that several genes put forward as being the best by the programs were in fact, regulated, making them unsuitable as reference genes. Additionally, eef1 which was found to be a suitable - though not the top ranked - reference gene for liver tissues in one year, was regulated in another.
\end{abstract}

Conclusions: Our study highlights the need for external validations of reference gene selections made by computer programs. Researchers need to be vigilant in validating and reporting the rationale for the use of reference gene in published studies.

\section{Background}

Quantitative real-time PCR (qPCR) has by far been the most widely used method for the measurement of transcript abundance. The method is applicable across most tissues and targets of interest, sensitive, relatively inexpensive and quick compared to Northern blotting. Most importantly, when employed appropriately, it allows for accurate quantification over a wide dynamic range of template amounts.

However, the level of accuracy depends upon various factors. The integrity of RNA contained in the original sample, storage conditions, the efficacy of various reagents and enzymes used in RNA extraction, purification, reverse

\footnotetext{
* Correspondence: alvin.setiawan@otago.ac.nz

Department of Zoology, University of Otago, 340 Great King Street, P. O. Box 56, Dunedin 9054, New Zealand
}

transcription and the actual qPCR, and the type of thermal cycler used are examples of factors that affect the accuracy of qPCR data. In order to take these sources of variation into account, an internal control (reference gene) is commonly used [1].

Reference genes need to have uniform transcript abundance across the different groups being compared (e.g, across treatments, developmental stage, conditions, etc). As such, normalizing transcripts abundance of target genes over that of a reference gene should, in theory, eliminate artifactual variation. It is clear however, that to date, not a single universal reference gene has been found, if it even exists at all [2]. Very often, genes that are stably expressed between treatments in one study system are found to be regulated in another. As such,

\section{Biomed Central}


careful consideration must be given to selecting and validating candidate reference genes [1].

More recently, many studies have employed a combination of multiple reference genes as normalizers [3-5]. This method commonly utilizes software packages, e.g., GeNorm [6], BestKeeper [7] and NormFinder [2], that are specifically designed to determine the most stable normalizer (i.e., with the least transcript abundance variability) amongst a set of candidates, and/or the most stable combination of genes based on their geometric averages. It is argued that the variation in the geometric average of several acceptably stable genes is usually smaller than that of any one of those genes alone, thus increasing normalizer stability [2]. Unfortunately, most of these studies only mention which genes are considered best by the software without validating if the genes are 'good enough'.

At the heart of the issue for most researchers, is whether or not reference genes are differentially regulated between compared groups (e.g., treatment, developmental stage, etc) [2]. In this study, we will illustrate the importance of validating the outcomes of these three reference gene selection programs. We do this by testing the transcript levels or normalization factor values ( $N F$ calculated in GeNorm) of software-selected reference genes for differences between sample groups using traditional non-parametric statistics (Mann-Whitney) and REST 2009 (Corbett Research Pty. Ltd. and Pfaffl, 2009). REST 2009 is a software application specifically created to statistically test qPCR data for pairwise differences between groups. For our purpose, we use the New Zealand shortfinned eel (Anguilla australis) as our study system.

Freshwater eels (Anguilla spp.) are catadromous teleosts that spawn in the deep-ocean [8-10]. The current study will evaluate the suitability of six candidate reference genes (eef1, $a c t b, o d c 1,18 s$, l36, nop14; Table 1) for qPCR analysis in the New Zealand shortfinned eel. We examined the stability of mRNA abundance of candidate reference genes in two tissue types (liver and ovary) between three groups of fish: juvenile sedentary (yellow) eels, migrating adult eels (silver) and 11-ketotestosterone
(11-KT) implanted yellow eels (11-KT group). We chose to compare these three groups due to our research interests regarding the transformation of yellow to silver eels (silvering). Silvering involves systemic changes to the physiology, morphology and behavior of eels, a necessary step before final sexual maturation and migration [11-13]. It is now well known that exogenous 11-KT implantation of yellow eels induces morphological and physiological changes consistent with silvering, in particular liver and ovary enlargement, and sexual development $[14,15]$. Three candidate genes were selected due to their common usage as references in many study systems $(e e f 1, a c t b, 18 s)$ and the remaining three because of our prediction that their mRNA levels should be stable due to their 'housekeeping' roles (Table 1; odc1, l36, nop14). Using three software applications (GeNorm, BestKeeper and NormFinder), we will determine the best reference gene candidate based on overall transcript stability and across the three groups. We will also validate these selected genes statistically and evaluate for differences between seasons. To our knowledge, this study is the first to formally select suitable reference genes for an anguillid fish and to subject the suitability of software-selected genes to scrutiny in any teleost.

\section{Results}

\section{qPCR assay validations}

All qPCR assays except that for eef1 of 2008 ovary samples (efficiency of 94\%) had amplification efficiencies between $95 \%$ and $105 \%$, and $R^{2}$ values of $\geq 0.985$. All qPCR assays produced a single amplicon as shown by single peaks during melting curve analyses. The identities of qPCR products were further confirmed through sequencing.

\section{Analyses of transcription stability}

Examination of threshold cycle $(\mathrm{Ct})$ values showed considerable variability among the different candidate reference genes (Figure 1), with different patterns between liver and ovary. The most stable and variable genes in the liver were $18 s$ and $o d c 1$, respectively, and in the ovary, $a c t b$ and $18 s$, respectively. Based on the $M$ value

Table 1 Candidate reference genes and their functions

\begin{tabular}{|c|c|c|}
\hline Gene name & $\begin{array}{l}\text { Gene } \\
\text { abbreviations }\end{array}$ & Function \\
\hline Elongation factor-1 $\alpha$ & eef1 & Catalysation of GTP-dependent binding of amynoacyl-total RNA to the ribosome; translational factor \\
\hline B-actin & Actb & Component of the cytoskeleton and mediates cell motility \\
\hline $\begin{array}{l}\text { Ornithine } \\
\text { decarboxylase } 1\end{array}$ & odcl & $\begin{array}{l}\text { Involved in the urea cycle as rate limiting enzyme in polyamine synthesis, carboxylating L-onithine into } \\
\text { diamine putrescine }\end{array}$ \\
\hline 18 s ribosomal RNA & $18 \mathrm{~s}$ & Part of the small ribosomal subunit \\
\hline $\begin{array}{l}60 \text { S ribosomal protein } \\
\text { L36 }\end{array}$ & 136 & Smallest protein in the large subunit of the ribosome \\
\hline Nucleolar Protein 14 & nop 14 & Processing pre $18 \mathrm{~s}$ rRNA and export of $40 \mathrm{~s}$ pre-ribosomal unit to cytoplasm \\
\hline
\end{tabular}




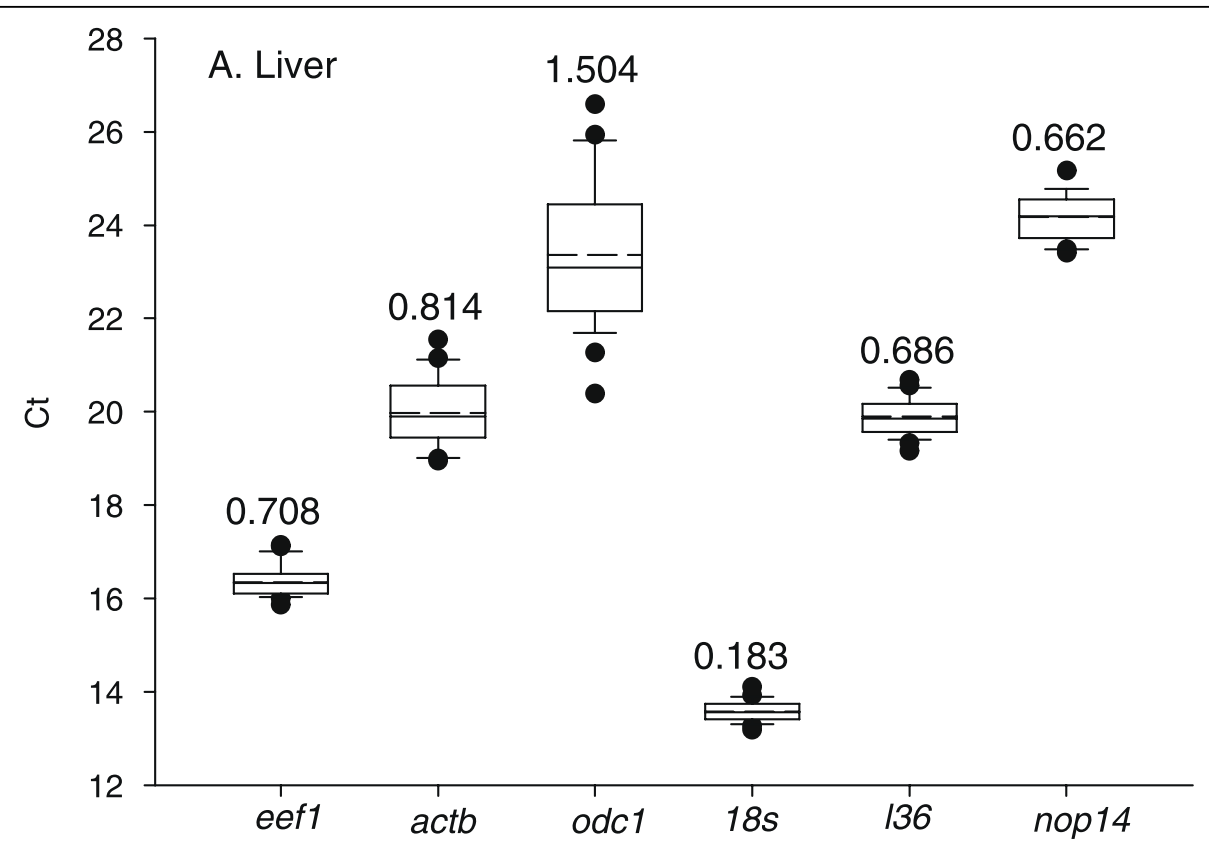

Candidate reference genes

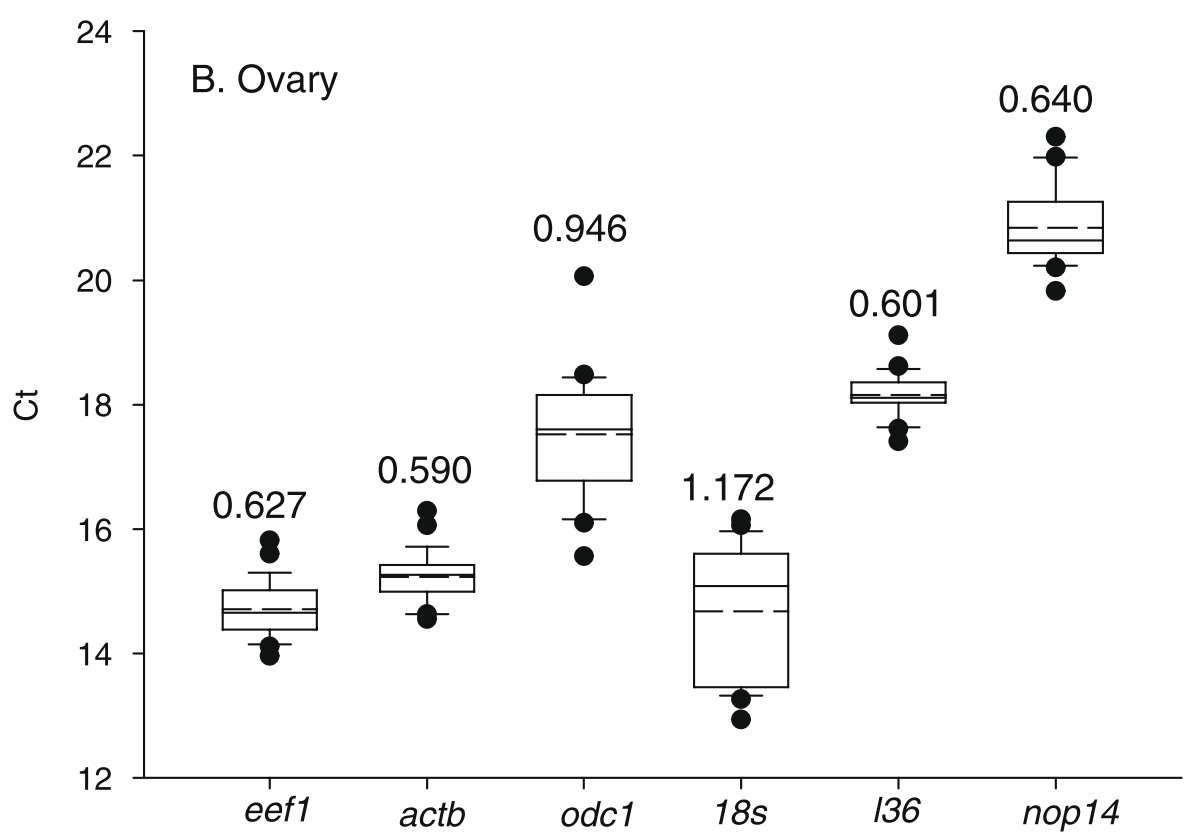

Candidate reference genes

Figure 1 Overall variability of mRNA levels of candidate reference genes in liver (A) and ovary (B). Data are based on the threshold cycle $(\mathrm{Ct})$ values of $\mathrm{qPCR}$ of reference gene candidates on liver and ovary samples taken in summer 2009. Box-and-whisker plots denote median, upper and lower quartiles, and $10^{\text {th }}$ and $90^{\text {th }}$ percentiles of data. Dashed lines within bars denote the means. Values above bars denote $M$-value as calculated by GeNorm as a measure of overall stability. Lower values denote lower transcript abundance variability, and thus suitability as a reference gene. 


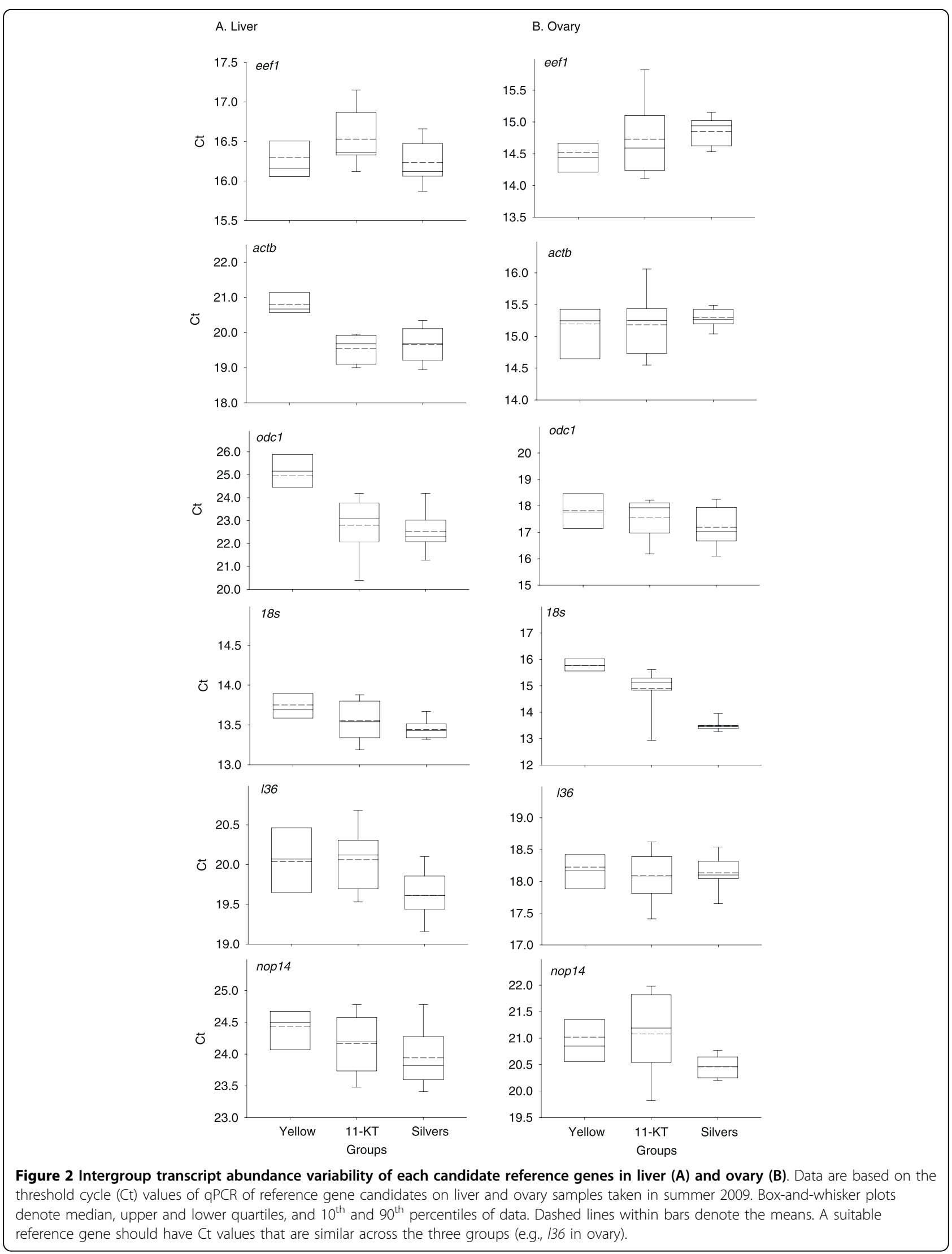


calculated in GeNorm, mRNA levels of all candidate genes except $18 s$ were more stable in the ovary than liver, a pattern that is replicated when calculated by NormFinder based on Stability value (data not shown). In general, the rankings obtained by GeNorm and BestKeeper correspond well with those based on this cursory analyses of overall mRNA levels (see below). Certain genes showed strong indications of being regulated, such as $a c t b$ and $o d c 1$ in the liver and $18 s$ in the ovary (Figure 2).

For liver samples, there is a broad agreement among the three programs, particularly between GeNorm and BestKeeper (Table 2). Thus, $18 \mathrm{~s}$ was consistently the top-ranked or part of the top-ranked pair of genes while $o d c 1$ was consistently the worst or second-worst performing gene for liver and ovary. GeNorm and BestKeeper gave identical decreasing ranking order for 136 , nop 14, actb and odc1. GeNorm and BestKeeper also selected eef1 as the second best and part of the best pair of genes, but eef1 was considered the second worst by NormFinder.

For ovary samples, there is only a moderate agreement between the three programs (Table 2). actb was ranked in the top half by all programs, and nop 14 in the top two selected by BestKeeper and NormFinder. In the ovary samples, $18 s$ is consistent in being the worst or second-worst performing gene

\section{Validation of reference genes}

Statistical analyses based on REST 2009 and MannWhitney provided virtually identical conclusions, with the only exception being those for $18 s$ liver on 2008 data (Table 3). Indeed, Mann-Whitney and REST 2009 showed a significant and not-significant difference between yellow and silver groups, respectively.

Most of the genes or pairs of genes selected by the three programs were not sufficiently stable among liver samples, showing strong regulation with treatment (yellow vs 11-KT) or developmental stage (yellow vs silvers) (Table 3 ). Only the eef1-18 $s$ combination and eef1 by itself were sufficiently stable across the three groups, and no significant pairwise differences were detected by REST 2009 or Mann-Whitney (Table 3). As indicated by the higher $p$ values in two pairwise comparisons, the eef1-18s combination is more stable than eef1 by itself. However, the high transcript abundance of $18 \mathrm{~s}$ may render it unsuitable as reference for lowly expressed genes. In these cases, eef1 would be a suitable reference.

For ovary, all of the genes or pairs of genes selected by the programs were sufficiently stable to act as references, except for nop 14 which seems to be down-regulated in silver eels (Table 3; Figure 2). Among the selected reference genes, a single gene - $l 36$ - was shown to perform best in terms of stability by yielding the lowest probability of a statistical difference between two pairwise comparisons.

The best reference genes identified from 2009 data were applicable for 2008 data for both liver and ovary (Table 3). The 2008 eef1-18 $s$ combination for liver and 136 for ovary were suitable for use as reference genes. However, we found significant differences in two sets of pairwise comparisons for liver eef1, making it unsuitable as a reference gene on this data set. To find out if any other reference genes are suitable, we ran the reference gene selection programs on the 2008 liver data and validated the selection statistically. The results indicated that $18 \mathrm{~s}$ used as a single reference gene was the only other viable option for 2008 liver samples, as validated by REST 2009. However, it should be noted that MannWhitney analyses showed a significant difference in $18 \mathrm{~s}$ mRNA levels between yellow and silver groups.

\section{Discussion}

In this study, we have for the first time selected reference genes that are suitable for use in qPCR of ovarian and liver samples from an anguillid eel. Our results show that for studies on the silvering of freshwater eels

Table 2 Ranking of reference gene candidates based on overall transcription stability

\begin{tabular}{|c|c|c|}
\hline & Liver & Ovary \\
\hline GeNorm*[M value] (without 18s) & $\begin{array}{l}\text { eef1-18 s }[0.316]<136<\text { nop } 14<a c t b<\text { odc } 1 \\
(\text { eef1-136 }[0.330]<\text { nop } 14<\text { <actb <odc1) }\end{array}$ & eef1-actb $[0.188]<136<$ nop $14<$ odc1 $<18 s$ \\
\hline BestKeeper [SD x-fold] & 18 s [1.13] <eef1 [1.19] <136<nop $14<a c t b<$ odc1 & $136[1.28]<$ nop $14<a c t b<$ eef1 $<18$ s <odc1 \\
\hline Normfinder [Stability value] (best pair) & $\begin{array}{l}18 \text { s [0.183] <nop } 14[0.189] \text { actb }<136<\text { <ef1 <odc1 } \\
(a c t b-136[0.100])\end{array}$ & $\begin{array}{l}\text { nop 14 }[0.125]<a c t b<136<\text { eef1 }<18 s<\text { odc1 } \\
\text { (nop 14-actb }[0.098] \text { ) }\end{array}$ \\
\hline
\end{tabular}

*GeNorm does not select the single best gene but the best pair of genes.

Rankings were based on overall transcription stability parameters as calculated by GeNorm (M-value), BestKeeper, (SD x-fold) or that calculated by a model based approach by Normfinder (Stability value). High transcript abundance of $18 \mathrm{~s}$ may make it unsuitable as a reference gene, therefore where $18 \mathrm{~s}$ had been selected by GeNorm as part of the best pair of genes, an additional analysis was conducted without $18 \mathrm{~s}$ (results in parantheses). Values in boxed parentheses [ ] indicate indices of stability of the top ranked gene or pair of genes, or the second highest if the top ranked gene was $18 \mathrm{~s}$. Lower scores denote greater transcription stability and suitability as a reference gene. Both GeNorm and Normfinder select the best pair combination of reference genes. 
Table 3 Pair-wise statistical analyses of the inter-group stability of selected reference genes

\begin{tabular}{|c|c|c|c|c|c|c|c|}
\hline \multirow[b]{2}{*}{ Tissue } & \multirow{2}{*}{$\begin{array}{l}\text { Group comparisons } \\
\text { Reference genes }\end{array}$} & \multicolumn{2}{|c|}{ Yellow vs $11-\mathrm{KT}$} & \multicolumn{2}{|c|}{ Yellow vs Silver } & \multicolumn{2}{|c|}{ 11-KT vs silver } \\
\hline & & $\begin{array}{l}p \text { based on } \\
\text { REST } 2009\end{array}$ & $\begin{array}{l}p \text { based on } \\
\text { Mann-Whitney }\end{array}$ & $\begin{array}{l}p \text { based on } \\
\text { REST } 2009\end{array}$ & $\begin{array}{l}p \text { based on } \\
\text { Mann-Whitney }\end{array}$ & $\begin{array}{l}p \text { based on } \\
\text { REST } 2009\end{array}$ & $\begin{array}{l}p \text { based on } \\
\text { Mann-Whitney }\end{array}$ \\
\hline \multicolumn{8}{|l|}{2009} \\
\hline \multirow[t]{6}{*}{ Liver } & eef1-18 s (GeNorm) & 0.898 & 0.815 & 0.071 & 0.074 & 0.067 & 0.190 \\
\hline & eef1-136 (GeNorm) & 0.457 & 0.481 & 0.115 & 0.167 & 0.012 & 0.031 \\
\hline & $\begin{array}{l}18 \mathrm{~s} \text { (BestKeeper, } \\
\text { Normfinder) }\end{array}$ & 0.085 & 0.093 & $<0.001$ & 0.001 & 0.243 & 0.297 \\
\hline & eef1 (BestKeeper) & 0.187 & 0.114 & 0.651 & 1.000 & 0.060 & 0.094 \\
\hline & nop14 (NormFinder) & 0.224 & 0.321 & 0.040 & 0.059 & 0.105 & 0.387 \\
\hline & actb-136 (Normfinder) & 0.002 & 0.002 & $<0.001$ & $<0.001$ & 0.238 & 0.297 \\
\hline \multirow[t]{4}{*}{ Ovary } & eef1-actb (GeNorm) & 0.704 & 0.073 & 0.281 & 0.093 & 0.525 & 0.546 \\
\hline & I36 (BestKeeper) & 0.533 & 0.673 & 0.638 & 0.673 & 0.784 & 0.863 \\
\hline & nop14 (NormFinder) & 0.850 & 0.963 & 0.007 & 0.011 & 0.030 & 0.050 \\
\hline & $\begin{array}{l}\text { nop 14-136 } \\
\text { (NormFinder) }\end{array}$ & 0.899 & 0.673 & 0.079 & 0.139 & 0.135 & 0.136 \\
\hline \multicolumn{8}{|l|}{2008} \\
\hline \multirow[t]{6}{*}{ Liver } & $\begin{array}{l}\text { eef1-18 s (2009 } \\
\text { best) }\end{array}$ & 0.082 & 0.079 & 0.892 & 1.000 & 0.166 & 0.113 \\
\hline & eef1 (2009 $2^{\text {nd }}$ best) & 0.002 & 0.004 & 0.283 & 0.356 & 0.011 & 0.019 \\
\hline & eef1-136 (GeNorm) & 0.006 & 0.006 & 0.869 & 0.905 & 0.006 & 0.006 \\
\hline & $18 s$ (BestKeeper)* & 0.308 & 0.549 & 0.422 & 0.053 & 0.884 & 0.063 \\
\hline & nop14 (Normfinder) & 0.047 & 0.053 & 0.038 & 0.035 & 0.001 & 0.003 \\
\hline & $\begin{array}{l}\text { nop 14-actb } \\
\text { (Normfinder) }\end{array}$ & 0.343 & 0.549 & 0.002 & 0.003 & 0.027 & 0.024 \\
\hline Ovary & I36 (2009 best) & 0.307 & 0.321 & 0.924 & 0.730 & 0.321 & 0.298 \\
\hline
\end{tabular}

* $18 \mathrm{~s}$ can only be considered the best for 2008 liver with qualifications as Mann-Whitney test showed significant difference between Yellow and Silver groups. The top ranked candidate reference genes as selected by GeNorm, BestKeeper and NormFinder were validated using REST 2009 (QIAGEN 2009 ; see text for explanation) and Mann-Whitney. To reduce Type II error, differences are considered significant at $p \leq 0.055$ (see text for further explanation). Significant difference between any two groups indicates unsuitability as reference genes due to lack of stability across groups. Figures in bold denote the best reference gene(s) based on inter-group stability. The second best option is also denoted in bold when the best included $18 \mathrm{~s}$ (e.g, liver). The best or second best reference gene(s) were applied to the 2008 data. Where it performs poorly (e.g., eef1 liver data), the programs were used to select the top ranked candidate gene based on 2008 data, with the statistical validation of the results also shown above.

and the involvement of $11-\mathrm{KT}$ in this event, the transcript levels for $l 36$ and the combination of eef 1 and $18 s$ are suitable for use as references in ovary and liver tissues, respectively. More importantly, we have for the first time demonstrated a method to validate the conclusions made by reference gene selection programs. Indeed, our validation method has surprisingly shown that a single gene ( $l 36$ in ovary) can perform better in terms of intergroup stability than a combination of genes.

Due to the widespread use of qPCR, it is unsurprising that reference gene selection programs are commonly used and form a critical element of publication of qPCR data. However, this study has highlighted several reasons for why external validations of the conclusions drawn from such programs are needed.

First, just as there is no single universal reference gene, no single program could provide the optimal reference genes for all situations. As can be expected from the different algorithms and assumptions employed, the three programs often do not agree on the best gene or rankings of genes [16]. The optimal gene(s) for liver and ovary, and even liver itself between seasons, were selected by different programs. We highly recommend that researchers interested in computer-assisted reference gene selection use multiple programs. It is encouraging that this approach has been adopted by many similar studies [16-20].

Second, the optimal reference genes selected by a program can only be as good as their candidates. In our case, ovary had greater overall transcript stabilities than liver for all but one gene $(18 s)$. This is consistent with our findings that most program-selected reference genes performed satisfactorily for ovary, while the opposite was found for liver where only two out of six selected genes passed statistical validation.

Third, differences in study design or context may affect the performance of reference genes, even within the same species. In this study, we show that year and season affected the performance of eef1 as a reference gene. It performed satisfactorily for samples taken in summer 2009 but showed a strong effect of treatment 
in the autumn 2008. Changes in reference gene suitability due to differences in study design (e.g., in vivo vs in vitro) or developmental stage have been reported in many studies (e.g., locusts [17], cerebral ischaemia in rats [21], channel catfish [22]). Thus researchers need to be vigilant in validating the reference genes used in every study.

All three potential problems described above could be mitigated by using an independent statistical validation method. REST 2009 was written by the same group that produced BestKeeper, and its conclusions very closely matched the independent Mann-Whitney tests which strongly suggest that it is a suitable validating program. We therefore, recommend the use of REST 2009 because its specific design for qPCR data analysis circumvents the difficulties of parametric statistical analyses on data based on proportions, such as those generated by qPCR [23]. However, other methods of qPCR data analyses are available (reviewed by Pfaffl et al 2009) and may be equally or more suitable, such as when analyses other than pair-wise comparisons are required.

There has been a realization that a great number of publications of qPCR data do not include sufficient information to allow for evaluation of reliability of the results [22,24]. One of the key description pertains to the selection of reference genes (selection procedure, validity, etc), yet, this information is often not provided. Fewer still indicate whether or not reference genes are stably transcribed across the compared groups, with many simply citing previous research that used the same genes in a similar study system. Our findings convincingly show that such approaches are inadequate as a matter of due diligence.

\section{Conclusions}

We suggest that all reporting of normalized qPCR data include the following information: 1) Justification/rationale for the selection of the reference genes used (e.g., selected using computer programs, previous use in a similar study system, etc), and 2) whether or not the mRNA levels of reference genes are different between the experimental groups.

\section{Methods \\ Sampling}

The main sampling was conducted in the austral summer of 2009 (February - March 2009). Female yellow eels $(n=20)$ and silver eels $(n=10)$, weighing between 800-1200 g, were caught by fyke net from Lake Ellesmere, Canterbury, New Zealand. Within 48 h of capture, they were intraperitoneally implanted with passive-integrated-transponder tags. At the same time, the silver and half of the yellow eels were given placebo implants (30 mg, 95\% cholesterol, 5\% cellulose), while the remaining yellow eels received $11-\mathrm{KT}$ implants (same size and composition as placebo, but with $1 \mathrm{mg}$ of 11 $\mathrm{KT})$. Eels were then transferred to a salmon raceway (35 m $\times 5 \mathrm{~m}$; New Zealand King Salmon Hatchery, Tentburn, Canterbury, New Zealand) for 28 days to allow the effects of $11-\mathrm{KT}$ to be manifested in treated eels. Water was kept at a depth of $\mathrm{c} .30 \mathrm{~cm}$ with a unidirectional gentle flow. At the end of the exerperimental period, all eels were sacrificed with an overdose of anaesthetic (benzocaine) and liver and ovary samples taken and flash frozen in liquid nitrogen until storage in a $-70^{\circ} \mathrm{C}$ freezer.

Our 2009 study was a refinement of one conducted in 2008. This earlier study was carried out later in autumn (April - May 2008), with a shorter captivity period (21 days). Data from the 2008 study were used to evaluate if selected reference genes (on the basis of 2009 data) were suitable for use between seasons.

\section{RNA extraction and cDNA synthesis}

Total RNA was extracted from frozen tissue samples ( $<100 \mathrm{mg}$ ) using TRIZOL (Invitrogen) according to the manufacturer's instructions, and quantified using a spectrophotometer (NanoDrop ND 1000, Thermo Fisher Scientific). The quality of RNA samples were ascertained using an Agilent Bioanalyzer 2100 (Agilent Techonologies), according to the manufacturer's instructions. All RNA samples were shown to be of high integrity, with clear and distinct peaks at the $18 \mathrm{~S}$ and $28 \mathrm{~S}$ areas. Liver RNA samples all had RNA integrity numbers (RIN) of $\geq 9$ 9.0. However, we detected very high amounts of small RNA in ovary samples, particularly for those of yellow eels (see Additional file 1: representative electropherograms of ovary and liver RNA). This observation was consistent and was also encountered by a colleague (Dr Yuichi Ozaki) in his ovary samples. As a result, the software could not calculate RIN for ovary samples of yellow eels, but could do so for those of silver eels (RIN $\geq 8.0$ ). Five micrograms of total RNA were then treated with Turbo DNA-free (Ambion) according to manufacturer's instructions to minimize potential genomic DNA contamination, and quantified using spectrophotometry. Information from the manufacturer stated that DNAse treatment were able to reduce DNA contamination in RNA samples by 5.4 million fold (Ambion 2009). Our own analyses conducted by comparing the Ct of DNAse treated and untreated liver cDNA showed a 512 fold reduction (99.8\% reduction). One microgram of DNAse treated total RNA was then reverse-transcribed using High Capacity cDNA Reverse Transcription Kit with RNAse Inhibitor (Invitrogen) using random hexamer 
primers. The resulting $20 \mu \mathrm{l}$ cDNA volume was finally diluted with $60 \mu \mathrm{l}$ deionized water to make a cDNA concentration of $12.5 \mathrm{ng}$ original total $\mathrm{RNA} / \mu \mathrm{l}$.

\section{Cloning of target genes for sequencing and making of standards}

We have cDNA sequence information for elongation factor-1 (eef1) and $\beta$-actin (actb) for A. australis from previous work (e.g., Lokman et al 2007). Primers for $18 s$ rRNA were designed based on the published sequence for $A$. australis (FM946133). Expressed sequence tags obtained after suppressive subtractive hybridization of two ovarian libraries from $A$. australis (Lokman, unpubl. data) yielded the sequence information for eel orthologues of $l 36$, a ribosomal protein, and nucleolar protein-14 (nop14). Degenerate primers for ornithine decarboxylase-1 (odc1) were designed on the basis of conserved motifs among odc1 orthologues from several teleost fish. Complementary DNAs were cloned into plasmids for sequencing or development of qPCR standards. Cloning parameters (primer sequences, melting temperature, amplicon sizes and identity at the nucleotide levels with known sequences) are shown in Table 4.

Partial target gene cDNAs were amplified from ovary or liver templates using PCR (Bioline: Biotaq Red DNA Polymerase, $10 \times \mathrm{NH}_{4}$ Buffer, $50 \mathrm{mM} \mathrm{MgCl} 2$ Solution). PCR products were electrophoresed, and amplicons of expected sizes extracted from the gel using the MinElute Gel Extraction Kit (Qiagen). Complementary DNAs were then ligated into pGEM T-Easy Vector (Promega) according to manufacturer's instructions. Ligated plasmids were transfected into Escherichia coli XL-1 Blue, grown overnight and single colonies amplified in $2 \mathrm{YT}$ medium. Plasmid was isolated using the Qiaprep Spin Miniprep Kit (Qiagen) and sequenced (Allan Wilson Centre Genome Service, Palmerston North, New Zealand) using M13 forward and reverse primers. Sequence identity was confirmed using the Basic Local Alignment
Search Tool in the NCBI database http://blast.ncbi.nlm. nih.gov/Blast.cgi. Sequences were aligned with those known for the species or those of other teleosts. All cloned fragments were shown to have high identity with known sequences (Table 4).

Purified plasmids were linearized using restriction enzyme (Spe I or Nco I, Roche Diagnostics), and subsequently mixed with 10 volumes TE buffer and 10 volumes phenol:chloroform:isoamyl-alcohol (PCI; 25:24:1) to inactivate enzymes and remove protein residues. Following centrifugation and precipitation by sodium acetate and ethanol [25], plasmid-insert constructs were dissolved in TE buffer, quantified by spectrophotometry, and serially diluted for use as standards in $\mathrm{qPCR}\left(10^{0}-10^{-6} \mathrm{ng}\right.$ linearised plasmid/ $\left.\mu \mathrm{l}\right)$.

\section{qPCR}

Primers for qPCR (Table 5) were nested within the cloned cDNA of each target gene. Due to lack of genomic information, we were not able to design primers spanning intron-exon boundaries. However, as RNA was DNAse-treated prior to reverse transcription, genomic contamination is kept at negligible levels. All samples for a particular tissue type were assayed in duplicate on a single 96-well plate along with standards and a notemplate control (deionized water), thus eliminating inter-plate variability. Due to the high concentration of $18 s$ RNA in each sample, qPCR for this target was conducted on cDNA samples diluted $100 \times$ in deionized water. Assays were conducted in $20 \mu \mathrm{l}$ reaction volumes using Express SYBR GreenER reagent (Invitrogen) on a MX3000P (Stratagene, LaJolla, CA, USA) thermal cycler with a thermal profile of $50^{\circ} \mathrm{C}$ for 2 minutes, $95^{\circ} \mathrm{C}$ for 2 minutes, followed by 40 cycles of denaturation at $95^{\circ} \mathrm{C}$ $(30 \mathrm{~s})$, annealing between $62-64^{\circ} \mathrm{C}(30 \mathrm{~s}$; see Table 5 for specific annealing temperatures) and extension at $72^{\circ} \mathrm{C}$ (30 s). At the end of 40 cycles, a final denaturation step at $95{ }^{\circ} \mathrm{C}(1 \mathrm{~min})$ was followed by a melting curve analysis. The melting curve analysis according to the

Table 4 Cloning parameters for candidate reference genes*

\begin{tabular}{|c|c|c|c|c|c|}
\hline Gene & Primers $(5 \mu \mathrm{M})$ & Accession number & $\begin{array}{l}\text { Anneal. temp. } \\
\left({ }^{\circ} \mathrm{C}\right)\end{array}$ & Frag. size (bp) & Seq. identity (ref. species, accession number) \\
\hline$e e f 1^{\ddagger}$ & $\begin{array}{l}\text { FW: atgggaaaggaaaagatccacatca } \\
\text { RV: tcaagcttcttgccagaacgacggt }\end{array}$ & HM367094 & 52 & 1163 & 99\% (A. anguilla, EU407825.1) \\
\hline$a c t b$ & $\begin{array}{l}\text { FW: agagctacgagctgcctgac } \\
\text { RV: cgggtggggcaataatct }\end{array}$ & HM357464 & 60 & 288 & 92\% (A. Anguilla, DQ493907.1) \\
\hline odcl & $\begin{array}{l}\text { FW: caratgatgacnttygayws } \\
\text { RV: ccrtcrttnacrtartacat }\end{array}$ & HM357466 & 60 & 581 & 84\% (Salmo salar, BT044794.1) \\
\hline $18 \mathrm{~s}$ & $\begin{array}{l}\text { FW: gtacacacggccggtacagt } \\
\text { RV: ggtaggcgcagaaagtacca }\end{array}$ & FM946133 & 60 & 302 & 100\% (A. Australis, FM946133) \\
\hline
\end{tabular}

*/36 (HM357467) and nop14 (HM357468) sequences were obtained whilst sequencing expressed sequence tags from a suppressive subtractive hybridization library (Lokman, unpubl. data).

${ }^{\ddagger}$ From Lokman et al (2007). 


\begin{tabular}{|c|c|c|c|c|c|c|c|c|}
\hline \multirow[t]{3}{*}{ Gene } & \multirow[t]{3}{*}{ Forward primer (conc.) } & \multirow[t]{3}{*}{ Reverse primer (conc.) } & \multirow{3}{*}{$\begin{array}{l}\text { Annealling } \\
\text { Temp. }\left({ }^{\circ} \mathrm{C}\right)\end{array}$} & \multirow{3}{*}{$\begin{array}{l}\text { Amplicon } \\
\text { Size (bp) }\end{array}$} & \multicolumn{4}{|c|}{ Amplification efficiency } \\
\hline & & & & & \multicolumn{2}{|l|}{ Liver } & \multicolumn{2}{|l|}{ Ovary } \\
\hline & & & & & 2008 & 2009 & 2008 & 2009 \\
\hline eef1 & $\begin{array}{l}\text { cccctgcaggatgtctacaa } \\
(200 \mathrm{nM})\end{array}$ & $\begin{array}{l}\text { agggactcatggtgcatttc } \\
(200 \mathrm{nM})\end{array}$ & 64 & 152 & $98 \%$ & $95 \%$ & $94 \%$ & $95 \%$ \\
\hline Actb & $\begin{array}{l}\text { aatcctgcggtatccatgag } \\
(250 \mathrm{nM})\end{array}$ & $\begin{array}{l}\text { gccagggatgtgatctcttt } \\
(250 \mathrm{nM})\end{array}$ & 62 & 154 & $101 \%$ & $105 \%$ & $104 \%$ & $102 \%$ \\
\hline odcl & $\begin{array}{l}\text { ggacgactcaaaggcagtgt } \\
(500 \mathrm{nM})\end{array}$ & $\begin{array}{l}\text { ccaatgtccagaagggtcat } \\
(500 \mathrm{nM})\end{array}$ & 64 & 234 & $96 \%$ & $104 \%$ & $96 \%$ & $104 \%$ \\
\hline $18 \mathrm{~s}$ & $\begin{array}{l}\text { ggatgcgtgcatttatcaga } \\
(200 \mathrm{nM})\end{array}$ & cgaaagttgatagggcagaca (200 nM) & 64 & 145 & $103 \%$ & $105 \%$ & $101 \%$ & $101 \%$ \\
\hline 136 & $\begin{array}{l}\text { cctgaccaagcagaccaagt } \\
(250 \mathrm{nM})\end{array}$ & $\begin{array}{l}\text { tctctttgcacggatgtgag } \\
(250 \mathrm{nM})\end{array}$ & 62 & 160 & $101 \%$ & $102 \%$ & $102 \%$ & $101 \%$ \\
\hline nop14 & gagagcgagagaggctgaag (250 nM) & $\begin{array}{l}\text { tttccactctccctcctgtg } \\
(250 \mathrm{nM})\end{array}$ & 62 & 185 & $101 \%$ & $101 \%$ & $100 \%$ & $100 \%$ \\
\hline
\end{tabular}

manufacturer's information involves a 1-minute melting segment of $95^{\circ} \mathrm{C}$, followed by a 30 second minute annealing step of $55^{\circ} \mathrm{C}$. The temperature is then increased in a stepwise fashion at $1^{\circ} \mathrm{C}$ increments until $95^{\circ} \mathrm{C}$, with the temperature held at each step for $30 \mathrm{sec}$ onds. Fluorescence data is collected at the end of each 30 second step. The data is presented as the first derivative of the fluorescence level $\left(-R^{\prime}(T)\right)$, with each peak in the data representing a qPCR product. Assays for each reference gene candidate produced a single peak.

We confirmed the identities of the qPCR products by the following method. We first collected representative ovary samples at the end of a qPCR assay for each reference gene candidate, which were then gel-electrophoresed. Consistent with the results of the melting curve analyses, only single bands at the expected sizes were visible for each reference gene candidate (data not shown). DNA fragments were then extracted from the gel using the MinElute Gel Extraction Kit (Qiagen) and sequenced at the University of Otago Department of Anatomy and Structural Biology.

\section{Selection of best reference genes}

We used three software applications specifically designed to measure transcript stability and to identify the best candidate gene or best gene combination from a selection of candidate genes, GeNorm, Bestkeeper and NormFinder. All three programs were written as Microsoft Excel Visual Basic macros and are freely available from the internet.

GeNorm is by far the most widely used program among the three with 1128 citations, compared to 126 for BestKeeper and 92 for NormFinder as of July 2008 (Vandesompele 2009). GeNorm considers the best reference genes as those which show the most stable transcript levels (relative quantities based on standards or delta-Ct) across all samples, disregarding a priori comparative groupings. Stability is measured as the average pairwise variation (SD of log-transformed ratios) of a candidate gene with each of the other candidate genes ( $M$ value). Lower $M$ value denotes higher stability. The program calculates the candidate gene with the highest transcript stability by a stepwise elimination of the least stable gene (highest $M$ value) until only two candidate genes are left. GeNorm then calculates the geometric means of this pair of genes to become the normalization factors (NF) that can be used to normalize the transcript levels of target genes. GeNorm also calculates the optimal number of reference genes, which is useful when geometric means of the two best reference genes are not sufficiently stable, or when the addition of another gene increases stability.

Unlike GeNorm, BestKeeper uses raw Ct as inputs, rather than relative quantities. The program has as its assumption that genes that are stably transcribed, and thus suitable to act as references, should be highly correlated with each other. Therefore, in addition to ranking suitable reference gene candidate based on SD of $\mathrm{Ct}$ values, it also performs repeated pairwise correlation analyses of all candidate genes. The geometric means of Cts of genes that are highly and significantly correlated with each other are then calculated as an index (the equivalent of NF in GeNorm).

NormFinder uses a different approach to selecting the best reference genes. Instead of measuring overall transcript stability, it takes into account possible variation across the different sample groups of interest. It uses a "model based approach to estimation of expression variation" (Andersen et al 2004) to select suitable reference genes. In this algorithm, intra- and inter-group variations are estimated, combined into a stability value and the candidate genes ranked accordingly. NormFinder also calculates the optimal combination of two candidate reference genes for use as normalizers particularly 
with regard to intergroup stability. In this case, we used GeNorm to calculate NF for the gene combination.

\section{Statistical validation}

All data were analyzed according to the instructions for each program. The best reference gene or combinations of genes that were selected by the programs were then statistically analyzed for differences between treatments or stages. The three groups being compared (yellow, silver and 11-KT) do not represent levels within a factor. The relationship between the three groups are that of stage (yellow vs silver), treatment (yellow vs 11-KT) and natural or artificial silvering (silver vs $11-\mathrm{KT}$ ). Therefore, it is not appropriate to use ANOVA or its equivalents.

Differences between groups were detected using nonparametric pairwise comparisons. We used REST 2009 (Corbett Research Pty. Ltd. and Pfaffl, 2009), a program specifically designed to conduct pairwise comparisons by using randomization and bootstrapping techniques. It allows the user to input multiple target genes, as well as reference genes. Based on its calculated normalized values of the target gene(s), the program then produces an output that tells the user the direction of difference between the groups, as well as the $\mathrm{p}$ value. The program is able to normalize the data over combinations of reference genes (based on the geometric averages). Therefore, REST 2009 is not a program originally designed to measure reference gene stability. However, it can provide a statistical output for stability between treatment groups for single genes input as 'reference', but not for combinations of reference genes.

Therefore, we had to 'trick' REST to measure the stability of reference gene combinations by including a dummy target gene variable which was given a uniform $\mathrm{Ct}$ value of 15. The candidate reference genes (e.g., actb, eef1, etc) were input as 'reference', the dummy gene was input as 'target'. Thus, the dummy gene was not meant to represent another normalizer, but merely a mathematical device to allow the stability of the combination of reference genes to be assessed. This method assumes that a stable combination of reference genes would not show a stably (uniformly) transcribed target gene - in this case the dummy gene - as being regulated. By testing for differences between groups for the dummy variable, we thus calculated the stability of the reference genes. In order to treat our analyses consistently, we utilized the dummy gene even when only one reference gene was being assessed (e.g., l36 for ovary). The results were virtually identical to when we did not use the dummy gene device (data not shown).

Due to this unorthodox method, we also utilized Mann-Whitney test in SPSS 17 to directly test for differences in transcript abundance or NF. Due to the multiple pair-wise comparisons, the Bonferroni correction dictates that statistical significance should be set at $\mathrm{p}<0.016$. However, since the onus is on minimizing Type II error, we have set our significance at a conservative level of $\mathrm{p}<0.055$. When $18 s$ was selected as the best gene by BestKeeper or NormFinder, the second best gene was also statistically validated, because $18 s$ may not be a suitable reference for many target genes.

\section{Validation of results using 2008 data}

Genes, or combination of genes that have been selected by the software applications as best were used as references in the 2008 data. We also tested their stabilities by statistically examining the differences in mRNA levels or NF between groups.

\section{Ethical approval}

All experiments were undertaken in compliance with the University of Otago Animal Ethics Committee and New Zealand national standards for animal research.

\section{Additional material}

Additional file 1: Representative electropherograms of ovary and liver RNA. This additional file contains examples of electropherograms of ovary and liver RNA in order to highlight the high concentrations of small RNA in the ovary samples, which prevented the calculation of RNA integrity numbers (RIN) for ovary RNA samples of yellow eels.

\section{Acknowledgements}

We are grateful to the New Zealand Foundation for Research Science and Technology for funding a postdoctoral fellowship to ANS (Ref: UOOX0715), and Graeme Davidson and other staff at New Zealand King Salmon Co. Ltd., for the use of their raceway. We are grateful for the assistance provided by Matthew Wylie, Steven Impey, Alexandra Bowles, and the technical staff at the Department of Zoology, University of Otago.

\section{Authors' contributions}

ANS conducted the sampling, cloning of candidate genes, RIA, QPCR, data analyses and manuscript preparation. PML conducted the SSH and provided plasmids for two candidate genes, provided sequences for eefl and actb through previous research, and assisted in the manuscript preparation. Both authors have read and approved the final manuscript.

Received: 24 February 2010 Accepted: 22 September 2010 Published: 22 September 2010

\section{References}

1. Vandesompele J, Kubista M, Pfaffl MW: Reference gene validation software for improved normalization. In Real-time PCR: Current Technology and Applications. Edited by: Logan J, Edwards K, Saunders N. Norfold: Caister Academic Press; 2009:47-64.

2. Andersen $\mathrm{CL}$, Jensen $\mathrm{J}$, Ørntoft TF: Normalization of real-time quantitative reverse transcription-pcr data: a model-based variance estimation approach to identify genes suited for normalization, applied to bladder and colon cancer data sets. Cancer Research 2004, 64:5245-5250.

3. Scharlacken B, de Graaf DC, Goosens K, Brunain M, Peelman LJ, Jacobs FJ: Reference gene selection for insect expression studies using quantitative real-time PCR: The head of the honeybee Apis melifera, after bacterial challenge. Journal of Insect Science 2008, 8:33. 
4. Olsvik PA, Søfteland L, Lie KK: Selection of reference genes for qRT-PCR examination of wild populations of Atlantic cod Gadus morhua. BMC Research Notes 2008, 2008:1:47.

5. Ouakad M, Bahi-Jaber N, Chenik M, Dellagi K, Louzir H: Selection of endogenous reference genes for gene expression analysis in Leishmania major developmental stages. Parasitology Research 2007, 101:473-477.

6. Vandesompele J, De Preter K, Pattyn F, Poppe B, Van Roy N, De Paepe A, Speleman F: Accurate normalization of real-time quantitative RT-PCR data by geometric averaging of multiple internal control genes. Genome Biology 2002, 3:0034.0031.

7. Pfaffl MW, Tichopad A, Prgomet C, Neuvians TP: Determination of stable housekeeping genes, differentially regulated target genes and sample integrity: BestKeeper - Excel-based tool using pair-wise correlations. Biotechnology Letters 2004, 26:509-515.

8. Inoue JG, Miya M, Miller MJ, Sado T, Hanel R, Hatooka K, Aoyama J, Minegishi Y, Nishida M, Tsukamoto K: Deep-ocean origin of the freshwater eels. Biology Letters 2010.

9. Aarestrup K, Okland F, Hansen MM, Righton D, Gargan P. Castonguay M, Bernatchez L, Howey P, Sparholt H, Pedersen MI, McKinley RS: Oceanic spawning migration of the European eel (Anguilla anguilla). Science 2009, 325:1660.

10. Chow S, Kurogi H, Mochioka N, Kaji S, Okazaki M, Tsukamoto K: Discovery of mature freshwater eels in the open ocean. Fisheries Science 2009, 75:257-259.

11. Lokman PM, Vermeulen GJ, Lambert JGD, Young G: Gonad histology and plasma steroid profiles in wild New Zealand freshwater eels (Anguilla dieffenbachii and $A$. australis) before and at the onset of the natural spawning migration. I. Females. Fish Physiology and Biochemistry 1998, 19:325-338.

12. Aoyama J, Miller MJ: The silver eel. In Eel Biology. Edited by: Aida K Tsukamoto K, Yamauchi K. Tokyo: Springer-Verlag; 2003:107-117.

13. Van Ginneken V, Durif C, Balm SP, Boot R, Verstegen MWA, Antonissen E, Van den Thillart G: Silvering of European eel (Anguilla anguilla L.): seasonal changes of morphological and metabolic parameters. Animal Biology 2007, 57:63-77.

14. Rohr DH, Lokman PM, Davie PS, Young G: 11-Ketotestosterone induces silvering-related changes in immature female short-finned eels, Anguilla australis. Comparative Biochemistry and Physiology A-Molecular and Integrative Physiology 2001, 130:701-714.

15. Lokman PM, George KAN, Divers SL, Algie M, Young G: 11Ketotestosterone and IGF-1 increase the size of previtellogenic oocyte from shortfinned eel, Anguilla australis, in vitro. Reproduction 2007, 133:955-967.

16. Sirakov M, Zarrella I, Borra M, Rizzo F, Biffali E, Arnone MI, Fiorito G: Selection and validation of a set of reliable reference genes for quantitative RT-PCR studies in the brain of the cephalopod mollusc Octopus vulgaris. BMC Molecular Biology 2009, 10.

17. Van Hiel MB, Van Wielendaele $P$, Temmerman L, Van Soest S, Vuerinckx $K$, Huybrechts $R$, Broeck JV, Simonet G: Identification and validation of housekeeping genes in brains of the desert locust Schistocerca gregaria under different developmental conditions. BMC Molecular Biology 2009, 10.

18. Kessler Y, Helfer-Hungerbuehler AK, Cattori V, Meli ML, Zellweger B, Ossent P, Riond B, Reusch CE, Lutz H, Hofmann-Lehmann R: Quantitative TaqMan (R) real-time PCR assays for gene expression normalisation in feline tissues. BMC Molecular Biology 2009, 10:106.

19. Li YL, Ye F, Hu Y, Lu WG, Xie X: Identification of suitable reference genes for gene expression studies of human serous ovarian cancer by realtime polymerase chain reaction. Analytical Biochemistry 2009, 394:110-116.

20. Hu RB, Fan CM, Li HY, Zhang QZ, Fu YF: Evaluation of putative reference genes for gene expression normalization in soybean by quantitative real-time RT-PCR. BMC Molecular Biology 2009, 10:93.

21. Gubern C, Hurtado O, Rodriquez R, Morales JR, Romera VG, Moro MA Lizasoain I, Serena J, Mallolas J: Validation of housekeeping genes for quantitative real-time PCR in in-vivo and in-vitro models of cerebral ischaemia. BMC Molecular Biology 2009, 10:57.

22. Small BC, Murdock CA, Bilodeau-Bourgeois AL, Peterson BC, Waldbieser GC: Stability of reference genes for real-time PCR analyses in channel catfish (Ictalurus punctatus) tissues under varying physiological conditions. Comparative Biochemistry and Physiology B-Biochemistry \& Molecular Biology 2008, 151:296-304
23. Pfaffl MW, Vandesompele J, Kubista M: Data analysis software. In Real-time PCR: Current Technology and Applications. Edited by: Logan J, Edwards K, Saunders N. Norfolk: Caister Academic Press; 2009:

24. Bustin SA, Benes V, Garson JA, Hellemans J, Huggett J, Kubista M, Mueller R, Nolan T, Pfaffl MW, Shipley GL, et al: The MIQE guidelines: Minimum Information for publication of Quantitative real-time PCR Experiments. Clinical Chemistry 2009, 55:611-622.

25. Ausubel FM, Brent R, Kingston RE, Moore DH, Seidman JG, Smith JA, Still K, (Eds): Short protocols in molecular miology: a compendium of methods from Current protocols in molecular biology. New York: Wiley 1995.

doi:10.1186/1471-2199-11-75

Cite this article as: Setiawan and Lokman: The use of reference gene selection programs to study the silvering transformation in a freshwater eel Anguilla australis: a cautionary tale. BMC Molecular Biology 2010 11:75.

\section{Submit your next manuscript to BioMed Central and take full advantage of:}

- Convenient online submission

- Thorough peer review

- No space constraints or color figure charges

- Immediate publication on acceptance

- Inclusion in PubMed, CAS, Scopus and Google Scholar

- Research which is freely available for redistribution
Ciomed Central 